\title{
Identity, Speech, and Equality
}

Nan D. Hunter

Georgetown University Law Center, ndh5@law.georgetown.edu

This paper can be downloaded free of charge from:

https://scholarship.law.georgetown.edu/facpub/1730

79 Va. L. Rev. 1695

This open-access article is brought to you by the Georgetown Law Library. Posted with permission of the author. Follow this and additional works at: https://scholarship.law.georgetown.edu/facpub

3 Part of the First Amendment Commons, and the Sexuality and the Law Commons 


\title{
IDENTITY, SPEECH, AND EQUALITY
}

\author{
Nan D. Hunter*
}

$\mathbf{M}$ $\mathrm{Y}$ experience as a litigator tells me that the First Amendment lias provided the most reliable path to success of any of the doctrinal claims utilized by lesbian and gay rights lawyers. Certainly no otlier block of cases can rival the success rate of the cases seeking recognition and even funding of lesbian and gay student organizations, all of whicl1 were brouglit on First Amendment grounds and ultunately won by plaintiffs. ${ }^{1}$

My experience as a lesbian teaches me that silence and denial have been the linclipims of second-class status. In almost any context that a lesbian or gay American faces, whetler it be the workplace, the military, the courts, or the family, the bedrock question is usually, is it safe to be out?

Patricia Cain's article on the history of the lesbian and gay legal movement provides a great service to scholars and activists in the field by taking the first steps im chronicling the story of gay rights hitigation efforts since the late 19tli century. I want to add to Professor Cain's project by identifying what I think is the most inıportant theme arising froin the noodern gay riglits inovement, which is the relationship between expression and equality.

The growth in the lesbian and gay riglits moveinent has generated more speech about sexuality. My argunent is that it also lias created a different kind of speech. Lesbian and gay riglits lawyers are figliting

* Associate Professor of Law, Brooklyn Law School. B.A. Northwestern University, J.D. Georgetown University Law Center.

I have been active in several of the cases and events discussed in this Article. I was cocounsel for plaintiffs in Gay Men's Health Crisis v. Sullivan and Finley v. National Endowment for the Arts, and I represented the Strafford County Family Planning Association in its negotiations with state and federal officials. In addition, I was an invited participant in the conference sponsored by the Centers for Disease Control in 1987.

1 See Gay and Lesbian Students Ass'n v. Gohn, 850 F.2d 361 (8th Cir. 1988); Gay Students Services v. Texas A \& M Univ., 737 F.2d 1317 (5th Cir. 1984); Gay Lib v. University of Mo., 558 F.2d 848 (8th Cir. 1977), cert. denied, 434 U.S. 1080 (1978); Gay Alliance of Students v. Matthews, 544 F.2d 162 (4th Cir. 1976); Gay Students Org. of the Univ. of N.H. v. Bonner, 509 F.2d 652 (1st Cir. 1974); Student Coalition for Gay Rights v. Austin Peay State Univ., 477 F. Supp. 1267 (M.D. Tenn. 1979); Wood v. Davison, 351 F. Supp. 543 (N.D. Ga. 1972). 
a battle in both judicial and legislative arenas over the fundamental question of the scope of public discourse. Our claims set forth the first serious deinand that speech about sexuality be treated as core pohitical speech. This development inarks a radical shift in First Amendınent doctrine, provoking a category crisis of whether to treat sexual speech as part of a shared social dialogue or as second-tier quasi-obscenity. The change in legal doctrine has altered political thought as well. It signals the conceptualization of sexuality-and specifically hoinosexuality-as a political idea.

Lesbian and gay rights legal claims have further complicated the expression-equality dynaimic. As it has einerged in lesbian and gay riglits case law, "identity" is a inultilayered concept. The idea of identity is more coinplicated and unstable than either simply status or conduct. It encoinpasses explanation and representation of the self. Self-representation of one's sexual identity necessarily includes a message that one has not inerely coine out, but tliat one intends to be out- to act on and live out that identity.

Notions of identity increasingly form the basis for gay and lesbian equality claims. Those claims inerge not only status and conduct, but also viewpoint, into one whole. To be openly gay, when the closet is an option, is to function as an advocate as well as a syinbol. The centrality of viewpoint to gay identity explams tlie logic behind what has becoine the primary strategy of anti-gay forces: the atteinpted penalization of those who "profess" homosexuality, in a series of "no proino homo" campaigns.

This essay analyzes the history of the relationship between expression, equality, and privacy in the state's regulation of sexuality. It traces the development of identity concepts in law and the general shift froin privacy to equality claims. Within this story, speecli is a constant thread; in a clianging context, lowever, First Amendnient assertions liave evolved into a new kind of claim. Identity politics lias led to identity speecl.

\section{The Right to Remain Silent}

One can date the first stage of the lesbian and gay civil rights inovement as occurring froin 1950 to 1975 . The three strands of doctrine that still dominate the field-privacy, equality, and expression-materialized during that period. Because the focus of the early cases and legislation was on sexual conduct, privacy becanie the primary intel- 
lectual bulwark of rights advocates. The Hart-Devlin debate about sodomy law, in which Millsian notions of liberty warred witl imvocations of communally-defined morality, provided the paradigmatic text. By the end of this period, however, equality and expression claims liad also emerged in gay rights higation.

Beginning after World War II, homosexuals as a class of persons were deinonized in U.S. politics as subversives capable of destroying society and the state. As a 1950 Senate report on sex perversion among federal workers warned, "[o]ne homosexual can pollute a Government office." In response to a panic about "[t]he [li]omosexual [m]enace,"3 the government sought to purge its military, its teaching corps, its workforce, and its immigrants of persons who were homosexual. President Eisenhower issued Executive Order 10,450 in 1953, which declared "sexual pervasion" inconsistent with the national security and thus rendered lesbians and gay men presumptively unfit for government employment. ${ }^{4}$

During this postwar period, the state used homosexual identity ${ }^{5}$ as a mechanisin of repression. It was the government that sought to impose identity as a public classification onto private acts. The state's ascertainment and exposure of private conduct created a forced public status, often accompanied by a confession, or forced speech. Knowledge of sexual conduct provided the ineans for identifying individuals and expelling them from public institutions, for-in the words of the Senate report-"detecting and removing perverts." In this franework, conduct defined homosexual identity.

2 Senate Comm. on Expenditures in the Exec. Dep'ts, Employment of Homosexuals and Other Sex Perverts in Gov't, S. Doc. No. 241, 81st Cong., 2d Sess. 4 (1950) [heremafter Eunployment of Hounosexuals in Gov't].

${ }^{3}$ See John D'Emilio, The Homosexual Menace: the Politics of Sexuality in Cold War America, in Passion and Power: Sexuality and History 226, 226 (Kathy Peiss \& Christina Siunmons eds., 1989).

4 Exec. Order No. 10,450, 18 Fed. Reg. 2489 (1953).

5 It is at best tricky and perhaps wrong to use the term "identity" in analyzing the social concepts extant during the early postwar period. Self-consciousness about a homosexual identity was then in its infancy among lesbians and gay men; although the African-American civil rights movement was starting to emerge as a pohitical force, the idea of identity politics had yet to develop. With these reservations, I nonetheless use the idea of "identity" in describing the process by which legal arguments helped shape a new social meaning for homosexuality and "the hounosexual."

6 Employment of Homosexuals in Gov't, supra note 2, at 9. 
Further, homosexuality became synonymous with a psychological type. The state treated the identity which it imposed as mental illness. The military took the lead in this shift during World War II, changing its approach to homosexuality from a brain disease model to a developmental personality model. ${ }^{7}$ In 1952 , Congress followed suit by repealing a 1917 provision in the immigration laws that had excluded individuals from e1mgrating to the Umited States who were persons of "constitutional psychopathic inferiority." tional inferiority" was explamed in a Senate report as ineaning persons with "tainted blood," or "medical traits" that would harm the populace of the United States.' In its place, Congress substituted a provision that einphasized not constituent defects, but a more inchoate psychological illness: "psychopathic personality."10 This latter phrase broadened the focus of the law to include "disorders of the personality. . . . Individuals with such a disorder may nanifest a disturbance of imtrinsic personality patterns, exaggerated personality trends, or are persons ill priniarily in terıns of society and the prevailing culture."11

The new category was necessary because Congress beheved that the previous approach had failed to identify hoinosexuals as a group to be excluded. The Senate report recommended that "the classes of mentally defectives ... be enlarged to include homosexuals and other sex perverts."12 By classifying the homosexual as a psychological type of person because he committed certain acts, Congress, like the 1military, merged honısexual acts and homosexual identity.

As a defense against public exposure, individuals sought to preserve their anonymity. Paradoxically, this desire for secrecy helped to create a zone in wlich a more pubhic and collective gay identity could grow. The hitigation surrounding gay bars and early gay orgamizations illustrates how the idea of privacy as a shield against the state functioned both to perpetuate secrecy and to help generate a visible social community.

7 Allan Berube, Coming Out Under Fire: The History of Gay Men and Women in World War Two 13, 139-41 (1990).

8 Senate Comm. on the Judiciary, The Immigration and Naturalization Systeins of the Uinited States, S. Rep. No. 1515, 81st Congress, 2d Sess. 343 (1950).

9 Id.

10 Id. at 345.

11 Id.

12 Id. 
After courts started to resist attempts to close the bars entirely, the state rehed on intermittent raids against lesbian and gay bars, ostensibly to momitor for unlawful conduct, as a tactic to repress the thennascent lesbian and gay subculture. ${ }^{13}$ Often these raids served primarily to expose the identities of bar patrons, sometimes by publication of naines in local newspapers. ${ }^{14}$ Fighting to end the pohice raids was necessary, at least in part, not only to preserve one's anonymity, but also to retain the opportunity to congregate in virtually the only gay- or lesbian-positive venues in cxistence at the time. Secrecy also figured prominently in concerns about joming homophile groups. The ability to inaintain secrecy of inembership strengthened organizations whose very existence undermined the closet. Secrecy furnished the precondition for its very opposite, expression. ${ }^{15}$

The success of privacy arguments also began the process of teasing acts and identity apart. Perhaps the most significant development in lesbian and gay rights law prior to the 1970 s occurred outside the realm of hitigation, when the American Law Institute, im publishing its Model Penal Code, dropped any prohibition of sodomy. ${ }^{16}$ Beginning with Illinois in 1961, twenty-one states decriminalized sodomy by adopting the Model Penal Code. ${ }^{17}$ Privacy concepts provided the philosophical basis for this legislative reform. ${ }^{18}$ In federal employment, the privacy-grounded claim that adverse einployment action

13 John D'Emilio, Sexual Politics, Sexual Communities: The Making of a Homosexual Minority in the United States 1940-1970 31-33, 49-50, 186-88 (1983); John D'Emilio \& Estelle B. Freedman, Intimate Matters: A History of Sexuality in America 290-94 (1988); Arthur S. Leonard, The Gay Bar and the Right to Hang Out Together, in Arthur S. Leonard, Sexuality and the Law: An Encyclopedia of Major Legal Cases 190-96 (1993).

14 D'Emilio \& Freedman, supra note 13 , at 294 . Occasionally, police attempts to record identities of gay individuals have been used tactically against the police. See, e.g., Cyr v. Walls, 439 F. Supp. 697, 704-05 (N.D. Tex. 1977) (allowing the individuals whose presence at various gay functions was recorded by the police to be added to the class in a civil riglits action against pohice officers).

15 See E. Carrington Boggan, Marilyn G. Haft, Charles Lister \& Jolin P. Rupp, The Rights of Gay People 10-12 (1975) [hereinafter The Rights of Gay People]. In this edition of the ACLU's guide for laypersons, in the chapter on speech and association, there is extensive discussion of low to keep one's group nembership secret and no discussion of the law pertaining to public protest.

16 Model Penal Code $\S 213.2$ cmt. 2 (Proposed Official Draft 1962, Revised Comments 1980).

17 Lesbians, Gay Men and the Law 88, 92 (William B. Rubenstein ed., 1993).

18 See Model Penal Code $\S 213.2$; see also H.L.A. Hart, Law, Liberty, and Morality 14-15 (1963) (noting how privacy concerns underlie the Model Penal Code's dropping of the prohibition against sodomy). 
could not be based on off-hours conduct led to first a United States Court of Appeals decision, Norton v. Macy, ${ }^{19}$ establishing that principle, then a Civil Service directive, ${ }^{20}$ and finally an amendment to the code governing federal workers. ${ }^{21}$

These refornns provided the legal shelter for conduct but not identity. The legislative repeals rendered sodomy a legally neutral act rather than a criminal one in a significant number of states. Federal workers gamed protection for the same "act of perversion" that had rendered them unemployable under Eisenhower's executive order. Gradually, homosexual conduct became imcreasmgly lawful, while the extrenie stigma associated with the person of the homosexual reniamed.

Affirmative declarations of homosexuality lay beyond the shelter of tolerance for secret acts. Speech about honosexuality was just beginning to enierge during this period. Until 1958, under the tendency-tocorrupt-niorals test, the test for obscenity that preceded the current standard, ${ }^{22}$ courts treated the proniotion or advocacy of homosexuality as obscene. Two milestone cases illustrate how the law judged honiosexuality as subject niatter under the First Amendment. In finding Radclyffe Hall's The Well of Loneliness obscene in 1929, a New York judge wrote that "[ $t]$ he book can have no moral value, smce it seeks to justify the right of a pervert to prey upon norinal members of a community, and to uphold such relationship as noble and lofty."23 In a ruling nearly thirty years later, the Ninth Circuit found the Mattachine Society's noonthly pohtical and hiterary magazme "One" to be

19417 F.2d 1161, 1165 (D.C.Cir. 1969) (holding that off-hours homosexual conduct could not be basis of dismisal unless it effected work performance).

20 Ashton v. Civiletti, 613 F.2d 923, 927 (D.C. Cir. 1979) (quoting Civil Service Bulletin, Dec. 21, 1993).

215 U.S.C. $\$ 2302(b)(10)$ (1988).

22 Roth v. United States, 354 U.S. 476, 489 (1957), abandoned the tendency-to-corruptinorals test, substituting a test that asked "whether to the average person, applying contemporary community standards, the doninant theme of the material taken as a whole appeals to prurient interest." The current standard, adopted in Miller v. California, 413 U.S. $15,24-25$ (1973), asks 1), whether the average person, applying contemporary community standards, would find that the work appeals to the prurient interest; 2), whether the work in question depicts or describes sexual conduct in a patently offensive way; and 3), whether the work as a whole lacks serious literary, artistic, political, or scientific value.

23 People v. Friede, 233 N.Y.S. 565, 567 (Mag. Ct. 1929). 
obscene and thus not mailable. ${ }^{24}$ The court based its finding of obscenity on one short story described as "nothing more than cheap pornography calculated to promote lesbianism" and one poem about gay male sexual activities that "pertains to sexual matters of such a vulgar and mdecent nature that it tends to arouse a feeling of disgust and revulsion."25 The judicial equating of the affirmation of homosexuality with obscenity ended when, without opinion, the Supreme Court reversed the Nimth Circuit in early 1958, citing its then-new obscenity standard that had dropped moral corruption as its touchstone. $^{26}$

Claims involving an exphicit combination of speech and due process grounds began in the 1970 s. These cases arose when public employees cliallenged discriminatory treatinent in their employment after having theniselves made their homosexuality public information. ${ }^{27}$ They brought hybrid claims based on due process and First Amendinent rights, rather than equality, and the courts essentially treated speech as a form of off-duty conduct, subject to the sanie kind of nexus analysis as the D.C. Circuit had promulgated in Norton. ${ }^{28}$ Their cases rose or fell on whether the courts found that their speecls had been sufficiently disruptive of the workplace to justify their firing. ${ }^{29}$

24 One, Inc. v. Olesen, 241 F.2d 772, 777 (9th Cir. 1957), rev'd, 355 U.S. 371 (1958). For a description of the magazine and its role in the homophile movement, see D'Emilio, supra note 13 , at $109-15$.

25 One, Inc., 241 F.2d at 777.

26 The Supreme Court's ruling consisted of one sentence reversing the lower court and a citation to Roth v. United States. One, Inc., 355 U.S. 371, 371. The Court's opinion thus did not address the specific question of whether promotion of homosexuality, at least if eroticized, could be a component of obscemity. In Manual Enters. v. Day, 370 U.S. 478 (1962), however, the Court ruled that nudity in gay male-oriented body-building magazines was no "more objectionable" than comparable female nudity "that society tolerates." Id. at 490 . The Day decision laid the groundwork for the growth of a national gay press. See Leonard, supra note 13, at 209.

27 Van Ooteghem v. Gray, 628 F.2d 488 (5th Cir. 1980), aff'd, 654 F.2d 304 (1981) (en banc), cert. denied, 455 U.S. 909 (1982); Singer v. Umited States Civil Serv. Comm'n, 530 F.2d 247 (9th Cir. 1976), vacated and remanded, 429 U.S. 1034 (1977); Acanfora v. Board of Educ., 491 F.2d 498 (4th Cir.), cert. denied, 419 U.S. 836 (1974); McConnell v. Anderson, 451 F.2d 193 (8th Cir. 1971), cert. denied, 405 U.S. 1046 (1972).

28 Norton v. Macy, 417 F.2d 1161, 1167 (D.C. Cir. 1969) (requiring a connection between employee's conduct and the efficiency of the service provided by the government agency).

29 Compare Van Ooteghem, 628 F.2d at 490-93 (holding that it was a violation of plaintiff's First Amendment right to free speech to fire him for addressing a public body on the civil rights of homosexuals) with McConnell, 451 F.2d at 196 (holding that the fact that plaintiff 
The next stage in the developing interrelationship between expression and equality emerged in the student organization cases. Beginning im the 1970s, lesbian and gay student organizations formed and immediately encountered refusals by universities to recognize them as legitimate campus groups. The universities argued that official recogmition would lead to criminal acts, relying primarily on the sodomy laws. Courts invariably ruled for the students, concludimg that the Brandenburg test requiring intentional imcitement to immediate lawless action ${ }^{30}$ had not been met. ${ }^{31}$ In the student organization cases, the judicial response quickly and comfortably drew on the preexistimg framework for analysis of the advocacy of unlawful conduct, making these easy cases. Courts and hitigators generally treated advocacy of homosexuality as advocacy of conduct. ${ }^{32}$

A focus on imdividual conduct dominated disputes about sexuality and law during the postwar period, both im efforts of repression and of defense. But its primacy had begun to weaken by the mid-1970s. The very successes of privacy claims set the stage for a focus on identity other than as defined by conduct. Declarations of homosexuality had started to complicate speech law and to imtertwine with notions of equality. Identity ouly partially determined by conduct proved to be a inuch more precarious concept and a more diffuse and shiftimg target for state repression.

\section{The Briggs Initiative: "No Promo Homo" Begins}

By consensus, the Stonewall rebellion in June 1969 marks the beginining of the lesbian and gay pohtical movement. ${ }^{33}$ During the

took activist role in impleinenting his unconventional ideas formed a sufficient basis for denying plaintiff employment).

30 Brandenburg v. Ohio, 395 U.S. 444, 447-48 (1969).

31 See Gay Student Servs. v. Texas A \& M Univ., 737 F.2d 1317, 1328 (5th Cir. 1984); Gay Lib v. University of Mo., 558 F.2d 848, 854 (8th Cir. 1977), cert. demed, 434 U.S. 1080 (1978); Gay Alliance of Students v. Matthews, 544 F.2d 162, 166 (4th Cir. 1976); Gay Students Org. of the Univ. of N.H. v. Bonner, 509 F.2d 652, 662 (1st Cir. 1974).

32 One district court, however, noted that "[h]ere we are not dealing with conduct, but with the advocacy of the acceptability of conduct." Student Coalition for Gay Rights v. Austin Peay State Uiniv., 477 F. Supp. 1267, 1274 (M.D. Tenn. 1979).

33 The event oceurred at the Stonewall Inn in Greenwich Village, when the bar's patrons spontaneously resisted what the police no doubt considered a routine raid. The resistance was all the more dramatic because most of the patrons were drag queens in full dress, although one observer credits a lesbian among the crowd with being the first to call on her coinpadres to fight back. The ensuing struggle became a pitched battle between gays and police that 
subsequent decade, municipal legislatures began to enact amendments to existimg civil rights ordmances that extended coverage to sexual orientation as a protected class. ${ }^{34}$ These breakthroughs in turn led to a series of repeal campaigns in 1977 in which voters eliminated civil rights protections in Dade County, Florida; St. Paul, Minnesota; Wichita, Kansas; and Eugene, Oregon, in rapid succession. ${ }^{35}$ Speech of various sorts obviously facilitated these events, but did not function opeuly as a constituent part of what was at stake. It was nearly ten years after Stonewall, in 1978, in the first political debate about homosexuality outside urban centers or limited enclaves like universities, that expression rather than conduct formed the core of the issue.

The Briggs Initiative appeared on the Noveınber 1978 California state ballot as a referenduni question that would have permitted the firing of any school employee who engaged in the "advocating, soliciting, imposing, encouraging or promoting of private or public homosexual activity directed at, or likely to coine to the attention of, schoolchildren and/or other employees."36 It was widely understood to be a vote on whether the state should fire gay teachers and thus purge that group froin the schools and from contact with children. ${ }^{37}$ This understanding of the meaning of Briggs was consistent with the older purge-the-homosexuals theme that had long dominated public discussion.

But the Briggs Initiative was configured to play a double role. It was framed im ternis of banning a viewpoint, the "advocating" or "promoting" of lomosexuality, rather than the exclusion of a group of persons. Lesbians and gay men easily fell within this proscription because to coine out is to implicitly, or often explicitly, affirm the value of homosexuality. For that reason, a Briggs-style law could be used to target all lesbian and gay school employees who had expressed their sexual orientation, except in the most furtive contexts.

continued for hours in the streets of the Village. For a contemporaneous discussion of Stonewall, see Lucian Truscott IV, Gay Power Comes to Sheridan Square, Village Voice, July 3,1969 , at $1,18$.

34 The Rights of Gay People, supra note 15, at 21.

35 Randy Shilts, The Mayor of Castro Street: The Life and Times of Harvey Milk 221 (1982).

36 Cal. Proposition 6, § 3(b)(2) (1978).

37 Shilts, supra note 35, at 212-51; Witch-hunting, The Economist, Oct. 28, 1978, at 50. 
The viewpoint target made the initiative more coinplicated, however. It threatened anyone, gay or straight, who voiced the forbidden ideas. Thus it sinultaneously discriminated against gay people while extending its aim to everyone not gay who supported them.

The proposed law did not merely include the two distmct elements of viewpoint bias and group classification. It merged them into one new concept. This merger-what I would describe as the formation of a legal construct of identity that mcorporates both viewpoint and status-would come to dominate both the right-wing strategy against gay rights and the claims of the lesbian and gay cominunity for equality.

Early opinion polls mdicated that the Briggs Initiative was likely to pass. $^{38}$ In efforts that becaine a model for the later response to AIDS, the California lesbian and gay cominunity mobilized on a scale that it had never before attempted. Thousands of volunteers, many pohitically active for the first time, jomed the anti-Briggs crusade, and massive fundraismg supported a sophisticated advertising and public relations cainpaign. ${ }^{39}$ These efforts contrasted with the meptness and underfunding of the pro-Briggs cainpaign and combined with statements opposing the initiative from a series of conservative political leaders, most famously Ronald Reagan. ${ }^{40}$ The initiative was defeated by a fifty-eight percent to forty-two percent vote. ${ }^{41}$

The Briggs Imitiative referenduni cainpaign marked the moment when American pohtics began to treat homosexuality as something more than deviance, conduct, or lifestyle; it marked the einergence of homosexuality as an openly pohtical claim and as a viewpoimt. That, in turn, laid the foundation for the emergence of a new analysis of speech about homosexuality. Instead of treatimg such speech as the advocacy of conduct, courts shifted to a consideration of gay speech

38 See Shilts, supra note 35, at 242; David B. Goodstein, Fighting the Briggs Brigade, The Advocate, June 14, 1978, at 6; Poll Shows a Major Shift on Prop 6, Gay Community News, Oct. 21, 1978, at 1 .

39 See Scott Anderson, After Victories, Leaders Ponder the Next Step, The Advocate, Dec. 27,1978 , at 8-9.

40 See Shilts, supra note 35, at 245-49; Sasha Gregory-Lewis, Californians Face Proposition 6 and Will it Be Written, Mene, Mene, Tekel Upharsin?, The Advocate, Nov. 15, 1978, at 712; Victory in California, Seattle; Miami Defeat, The Advocate, Dec. 13, 1978, at 9 [hereinafter Victory in California].

41 Victory in California, supra note 40 , at 9. 
as the advocacy of ideas. The once-bright boundary between sexual speech and pohtical speech began to fade.

A year after the Briggs vote, the California Supreme Court ruled that statements of homosexual identity constituted political speech protected by the state's labor code. ${ }^{42}$ In a conclusion still unique in judicial decisions, the court ruled that a complaint that the defendant discriminated against "manifest" hoinosexuals and homosexuals who make " 'an issue of their homosexuality" " stated a cause of action that defendants violated the labor code by trying to pressure employees to " "refrain from adopting [a] particular course or line of pohtical . . . activity." "43

Measured by these standards, the struggle of the homosexual commumity for equal rights, particularly in the field of employment, must be recognized as a political activity. ... [O]ne important aspect of the struggle for equal rights is to induce homosexual individuals to "come out of the closet," acknowledge their sexual preferences, and to associate with others in working for equal rights. ${ }^{44}$

This was the first ruling treating self-affirming "identity speech" as explicitly pohtical because of - rather than despite of-its expression regarding sexuality, and not as a surrogate for, or prediction of, conduct. ${ }^{45}$

By contrast, the federal courts, in adjudicating the constitutionality of language identical to the Briggs Imitiative, rehed on reasoning that avoided the question of whether promoting homosexuality could qualify as pohitical expression. Legislators in Oklalioma enacted the saine language rejected by voters in California, after Anita Bryant, a former Miss Oklalioma who had led the effort to repeal the Dade County civil rights provision, urged them to protect school children

42 Gay Law Students Ass'n v. Pacific Tel. and Tel. Co., 595 P.2d 592, 610-11 (Cal. 1979).

43 Id. at 611.

44 Id. at 610.

45 The Pacific Telephone case was settled with a $\$ 5$ million payment to the plaintiff class and the adoption by defendant of an antidiscrimination policy. Leonard, supra note 13 , at 417 . In a later case, the California Court of Appeals ruled that the Labor Code's provisions protecting employees' fundamental rights to engage in political activity free of employer interference also applied to expressions of sexual orientation. Soroka v. Dayton Hudson Corp., 1 Cal. Rptr. 2d 77, 87-88 (Cal. Ct. App. 1991) appeal docketed, No. 5024102 (Cal. 1992). In 1992, the Labor Code was amended to add an explicit protection. Cal. Lab. Code $\S 1102.1$ (West 1993). 
from persons who "profess homosexuality."46 The Tenth Circuit found the Oklahoma statute overbroad because it had the potential to reach such core political speech as a school employee's opinions im favor of adopting a civil rights law or repealing a sodomy law. ${ }^{47}$ The dissent attempted to create a new rule against incitement to sexual conduct, arguing that although advocacy of "violence, sabotage and terrorism" was protected under the Brandenburg test, advocacy of "a crime malum in se"- "a practice as universally condemned as the crime of sodomy" - should not qualify for First Amendment protection. ${ }^{48}$ Bryant's own phrase had captured the paradox, however: one "professes" a behief, not an act.

\section{HIV TESTING AS SPEECH}

With the advent of the HIV epidenic in the early 1980s, gay male sexuahity becaine a topic of widespread political discussion and debate. Although legal and social reaction ostensibly focused on the disease, the disease itself was so closely associated with gay men in the first years of the epidemic that much of the reaction seemed a euphemism for opinions of male homosexuality.

In a narrow sense, most of the case law generated by and about HIV falls outside the category of gay rights law. Litigators most often based antidiscrimination claims on disability, not sexual orientation. ${ }^{49}$ Privacy claims were frained as protection against intrusive medical tests, not the threat of forced disclosure of homosexuahty that many gay men anticipated from mandatory HIV testing. ${ }^{50}$

But in a broader and deeper sense, courts, Congress and state legislatures had begun a fight over which new social understanding about homosexuahity would supersede silence. At issue was the question of what information would coinprise public knowledge, and how the

46 Brief for Appellees at 2-3 n.3, Board of Educ. of Okla. City v. National Gay Task Force, 470 U.S. 903 (1985) (No. 83-2030).

47 National Gay Task Force v. Board of Educ. of Okla. City, 729 F.2d 1270, 1274 (10th Cir. 1984), aff'd per curiam, 470 U.S. 903 (1985). The Supreme Court ruled by an evenly divided vote; Justice Lewis Powell took no part in the case because of illness. See Leonard, supra note 13 , at 616.

48 National Gay Task Force, 729 F.2d at 1277 (Barrett, J., dissenting).

49 Arthur S. Leonard, Discrimination, in AIDS and the Law: A Guide for the Nineties 297 (Scott Burris et al. eds., 1993).

50 Scott Burris, Testing, Disclosure, and the Right to Privacy, in AIDS and the Law, supra note 49 , at 115 . 
government would define and enforce the boundaries of public discourse. Framed in this way, many aspects of AIDS law that we think of as falling within the doctrinal category of privacy really center on speech.

\section{A. Reexamining the Testing Debate}

This contest over public knowledge and discourse was fought first, and most significantly, im the policy debate over education versus testing. It quickly became a commonplace in policy discussions to note that, $i m$ the absence of a cure, prevention was the only weapon agaimst the spread of HIV. ${ }^{51}$ The contest then became how to define "prevention": Would that term be imterpreted to mean testing or education? ${ }^{52}$ The question became, in effect, which form of knowledge would be available in the public realm.

Education efforts, includimg safe-sex education, required a public discourse that was nonjudgmental of the individual and agnostic toward sexual practices. It sought to promote greater knowledge about sexualities and incited public discussion about specific sexual acts. Testing campaigns, by contrast, empliasized a private procedure that led to identification of those who were HIV-infected, and often to reporting of that information to public health authorities.

Two competing "right-to-know" campaigns began. Conservatives argued that the public inost urgently needed to know who was infected and thus who posed a danger. The gay community used public health arguments to justify opening public fora such as schools and broadcast media to an unprecedented discussion of male liomosexuality.

The combination of these arguments led to a two-part discourse by each side. AIDS activists argned for widespread knowledge and openness at the collective level and anonymity at the individual level,

51 See, e.g., Report of the Nat'l Comm'n on Acquired Immune Deficiency Syndrome, America Living with AIDS 19 (1991) ("Until a cure or a vaccine is found, education and prevention are the only hope for altering the course of the HIV epidemic.").

52 Dennis Altman, Legitimation through Disaster: AIDS and the Gay Movement, in AIDS: The Burdens of History 305 (Elizabeth Fee \& Daniel M. Fox eds., 1988); see also AIDS Research: Hearings on Dep'ts of Labor, Health and Human Servs., Education, and Related Agencies Appropriations for 1989, Subcomm. of the Comm. on Appropriations, 100th Cong., 2nd Sess. 294, 299 (1988) (written tesimony of Jeffrey Levi, National Gay and Lesbian Task Force) (arguing for a greater emphasis in government AIDS spending on education as compared to testing). 
especially in the context of the individual reporting information to the state. Conservatives countered with arguments for revelation of inforination about individuals to some state authority, together with silence about sexuality in the public, collective discourse.

At the level of individual knowledge, HIV testing in the mid-1980s, before treatinents became available, (usually) functioned as exposure of hoinosexuality witlı hittle or no benefit to the persons being tested. As a result, gay rights groups atteinpted to dissuade the Food and Drug Administration from licensing the antibody test in $1985 . .^{53}$ In the end, the antibody test saved the nation's blood supply and, in the process, probably averted what would liave been a far worse social panic had contaminated blood reinamed a real threat. But the test also began to be used in exactly the way that rights advocates feared-as a inarker for identification and exclusion. ${ }^{54}$

The testing debate within the administration chinaxed in 1987. In February of that year, the Centers for Disease Control ("CDC") lield a inassive conference on mandatory testing proposals for a variety of populations. Hundreds of persons attended the conference, and the major sessions were filmed and broadcast by video and television cameras froin platforms in the middle of cavernous rooins. CNN correspondents conducted interviews of public healtli leaders and activists from sets built outside the meeting lialls and billed its day-long coverage as the "national AIDS meeting." The outcoine of the conference was a inajor setback to proponents of forced testing; the consensus recommendations einpliasized voluntariness and confidentiality and urged the adoption of antidiscrimination protections. ${ }^{55}$

The CDC toned down these recommendations before transmitting thein upward in tlie chain of command, but retanied the basic focus

53 See Ronald Bayer, Private Acts, Social Consequences: AIDS and the Politics of Public Health 89-93 (1989); Dennis Altman, AIDS and the New Puritanism 74-78 (1986).

54 Almost immediately after hicensure, the U.S. military began mass HIV screening of all recruits and active duty personnel. Reeruits who tested positive were rejected for service and often informed of their HIV status with no counseling or information about the disease. Military use of the test was soon followed by adoption of mandatory testing programs by the Foreign Service and the Job Corps. Bayer, supra note 53, at 158-62; see also American Fed'n of Gov't Employees v. Department of State, 662 F. Supp. 50 (D.D.C. 1987) (rejecting the enjoining of the foreign service's mandatory AIDS testing).

5s Conference on the Role of AIDS Virus Antibody Testing in the Prevention and Control of AIDS, Closing Plenary Session: Reports from the Workshops, Transcript of Proceedings (Feb. 24-25, 1987). 
on consent and confidentiality. ${ }^{56}$ The issue reached the Domestic Policy Council that spring. Then Surgeon General C. Everett Koop won acceptance of a let-the-states-decide position on a number of testing proposals, but could not stop the administration from undertaking mandatory testing of federal prisoners and immigrants, groups more characterized by their vulnerability to government control rather than by any logical relationship to a risk of transmission. ${ }^{57}$

For both sides in the debate over testing, knowledge of individuals' status became an miportant fact in and of itself. For social conservatives, screening and identification of the HIV-infected became a kind of justified stigmata, a rite of expulsion, and a method of defining the boundary of commumity and politics to reject the alien. For AIDS activists, resistance to testing served as botll a protective barrier agamst tliose expulsions and also as a bargaining chip. Public liealtlı officials desperately needed the cooperation of the gay community in order for any prevention programs to succeed, and activists tacitly or explicitly souglit to trade cooperation in exchange for support of new laws banning discrimination based on HIV status or sexual orientation.

\section{B. Public Discourse and the Legacy of Briggs}

Altlougl the debates over individual testing still continue and reinain important, a noticeable cliange in focus has occurred. In 1987, the saine year that the testing controversy peaked, a major shift occurred in the debate as a whole, as it evolved from a contest primarily about knowledge of individual status to one increasingly about the scope of public discourse.

In 1985, the CDC began funding educational programs aimed at beliavior cliange, which included support for some ninovative programs undertaken by the Gay Men's Healtl Crisis ("GMHC"), a New York City group thiat provides education and otlier services to people infected with HIV. GMHC and other AIDS service organizations liad always used private funds to develop their most provocative materials, whicli sought to eroticize condoin use and otlier safe-sex

56 Public Health Serv. Centers for Disease Control, U.S. Dep't of Health and Human Servs., Recommended Additional Guidelines for HIV Antibody Counseling and Testing in the Prevention of HIV Infection and AIDS, at 9-13 (Apr. 30, 1987).

57 See Bayer, supra note 53, at 164 . The final recommendations were published at 36 Morbidity and Mortality Wkly. Rep. 509 (Aug. 14, 1987). 
practices. Officials at CDC became alarmed, however, by the potential for conservative backlash agamst the agency for supporting a gay organization engaged in controversial work. ${ }^{58}$ In January 1986, the CDC first promulgated restrictions on the content of federally-funded programs, requiring that all such materials must use language that "would be judged by a reasonable person to be unoffensive to most educated adults." 59

In 1987, this issue reached Congress. In October, Senator Jesse Helms introduced an amendment to the appropriations bill for the Department of Health and Human Services that forbade use of any CDC funds "to provide AIDS education, information, or prevention materials and activities that promote or encourage, directly or indirectly, homosexual sexual activities" 10 -language that closely tracked that of the Briggs Initiative. Unlike Briggs, however, the Helms bill was unstoppable. Opponents succeeded only in deleting the term "indirectly," thus arguably limiting its scope to the most graphic materials.

The Helms Amendment combined the Briggs Initiative's one-stroke targetimg of both gay people and pro-gay ideas with the most successful argument made by the anti-choice movement in the abortion debate: that public funds should not be used to "subsidize" activity associated with what conservatives paint as sexual permissiveness. The difference here was simply that the target group was gay men rather than imdigent women. And, unlike abortions, the funded activity, education, was public in its nature, raising the questions of how and on what terms the nation would discuss AIDS. In fact, gaytargeted educational campaigus were very unlikely to be seen outside gay venues, but the right launched an attack that spread from the safe sex coumics and erotic videos distributed in gay bars to sex education and condom availability in the schools.

The debate on adoption of the Helms Amendment centered on objections raised by Senator Helms to AIDS education efforts within

58 Marlene Cimons, AIDS Education Grants Frozen, L.A. Times, Dec. 4, 1985, at 12.

5951 Fed. Reg. 3431 (1986).

60133 Cong. Rec. 14,267 (1987). The Labor-Health and Human Services Appropriations Act for Fiscal Year 1988 provided that "none of the funds made available under this Act to the Centers for Disease Control shall be used to provide AIDS education, information, or prevention materials and activities that promote or encourage, directly, homosexual activities." Pub. L. No. 100-202, § 514(a), 101 Stat. 1329-289 (1988). 
the gay male community, specifically those of the GMHC. Senator Helms made clear, repeatedly, that his objections were based on his views of what was moral and that the purpose of his amendment was to insure that the content of AIDS education be made to conform to what he beheved to be moral precepts of behavior, which for him meant absolute opposition to homosexuality or any tolerance for it.

Senator Helms paraphrased the GMHC proposal, noting that AIDS education sessions (all of which were specifically targeted for gay male participants) mcluded discussions of "a positive sense of gay pride." ${ }^{.31}$ He continued:

Then ... we get to session 5 and session $6 \ldots$ This is entitled "Guidelines for Healthy Sex." . . The behavioral objectives of these two sessions included the ability to "list satisfying, erotic alternatives to high-risk sexual practices; identify erogenous areas of the body,"and here is liere [sic] I get embarrassed-"otler than the genitals, that produce an erotic response."

Oli boy....

There is no mention of any moral code . . . Good Lord, Mr. President, I may throw up. ${ }^{62}$

Senator Helms reiterated throughout the debate his intent that the amendment was designed to forbid publicly-funded AIDS education inaterials from advocacy of homosexuality: "Yes, it will require us to make a moral judgment. I think it is about time we started making some moral judgments and stop playing around with all those esoteric things and saying 'Yes but.' I believe, Mr. President, it is time to draw the line."63 Senator Helms concluded by stating: "What the amendment does is to propose that we ensure that any money spent for sucli purposes is not spent in such a way tliat even comes close to condoning or encouraging or promoting intravenous drug use or sexual activity outside of a sexually monogamous marriage including hoinosexual activities." 64

In the course of the debate, Senator Helms amended his original proposed language to focus its prohibitions specifically on materials

\footnotetext{
61133 Cong. Rec. 14,203 (1987).

62 Id.

63 Id. at 14,204 .

64 Id. at 14,208 .
} 
which promoted homosexual activities only, and not all premarital or extramarital activities, thereby accentuating the invidiousness of the targeted suppression. Inmediately before the final vote, Senator Helms sumined up the provision:

Earlier, Mr. President, on this floor, I read from grant presentation documents prepared by the Gay Men's Health Crisis of New York City. That is a corporation. It is unmistakably clear that those activities are being federally funded and are promoting and encouraging homosexuality.... Therefore, Mr. President, it should be clear that in adopting this amendment, if in fact it is adopted, this Senate is prohibiting further funding for programs such as those sponsored, operated by the Gay Men's Health Crisis Corp. that promote or encourage hoinosexual sexual relations. ${ }^{65}$

Restrictions on content reinamed in place for several years. The Helms language was rejected in the next year's appropriations bill, in favor of a provision that neutralized its anti-gay focus while retaiming some limitations on speech. The new language, known as the Kennedy-Cranston Amendinent, limited fundimg only if AIDS educational materials were "desigued" to encourage sexual activity, whether heterosexual or homosexual. ${ }^{66}$ Under this intent requirement, materials that were designed to reduce HIV transmission, but were erotic as part of that design, were supposed to be exeinpt from the limitation because they were not "solely and specifically" intended to encourage sexual activity. ${ }^{67}$ Senator Helms vehemently opposed the Kennedy-Cranston Amendinent, accusing its supporters of attempting to render his own approach "nugatory."68

In fact, however, despite the Kennedy-Cranston Amendinent, the CDC retamed its own "offensiveness" restrictions until they were

65 Id. at 14,219.

66 The Kennedy-Cranston Amendment stated:

"Notwithstanding any other provision of this Act, AIDS education programs funded by the Centers for Disease Control and other education curricula funded under this Act dealing with sexual activity-

(1) shall not be designed to promote or encourage, directly, intravenous drug abuse or sexual activity, homosexual or heterosexual.

67134 Cong. Rec. 10,025 (1988) (statement of Sen. Cranston); see also id. at 17,005 (statement of Sen. Kennedy) (stating that the bill was written so as to prevent funding of programs designed solely to promote or encourage sexual activity).

68 Id. at 10,027 . 
found invalid by a federal district court in $1992,{ }^{69}$ a ruling that the government declined to appeal. The court found the language of "offensive[ness]" to be void for vagueness ${ }^{70}$ and also ruled that the CDC's standard violated an AIDS-related statute that prohibited federal funding only to materials that were found to be obscene. ${ }^{71}$

In suin, although few of the judicial opinions addressing AIDSrelated issues focus on expression, the politics of speech profoundly shaped AIDS policy. AIDS policies, in turn, transformed public discourse on liomosexuality, more so than any otlier event to that time, including Stonewall, Briggs, or the battles over municipal and state civil rights laws.

By the the late 1980s, the angle of attack was clearly directed at homosexual ideas as embodied in the gay community and not siniply at gay persons as such. Dozens of AIDS service organizations, many openly affiliated witl gay community groups, received millions of dollars of CDC funding for education and other prevention efforts. Neither the Reagan Administration nor Senator Helins ever attempted to exclude all gay persons or groups as grantees; even if there had been the desire for such an exclusion, it was practically infeasible and pohtically iniplausible. The attack on gay identity had now centered on expression and "no promo homo" was its theme song.

\section{Beyond AIDS: "No Promo Homo" REVISITED}

The "no promo lomo" language that originated in the Briggs Initiative and was used to restrict AIDS education became the model for many anti-gay legislative initiatives, in the United States and beyond. Arizona enacted criteria for AIDS education materials in public schools that prohibited any local district from providing instruction that promoted a homosexual lifestyle, portrayed homosexuality as a positive alternative lifestyle, or suggested that some methods of sex are safe methods of homosexual sex. ${ }^{72}$ Alabama adopted similar legis-

69 Gay Men's Health Crisis v. Sullivan, 792 F. Supp. 278, 304 (S.D.N.Y. 1992).

$70 \mathrm{Id}$. at 302 (holding that "the grant terms are too vague to apply in a non-arbitrary manner").

71 Id. at 291 (finding that "in using the 'offensiveness' criteria, the CDC has contravened its statutory authority which bars funding of only of obscene, not offensive mateial").

72 See Ariz. Rev. Stat. Ann. § 15-716(C) (1992). Specifically, the statute states: "No district shall include in its course of study instruction which: 
lation. ${ }^{73}$ In Britain, Clause 28 of the Local Government Act of 1988 stated that local governments could not "promote homosexuality or pubhish inaterial with the intention of promoting of homosexuality" or "promote the teaching ... of the acceptability of homosexuality as a pretended family relationship." 74 Nor could government funding go to private entities engaged in those acts. ${ }^{75}$

Meinbers of Congress also seemingly have become fond of the "no promo homo" principle, reinvoking it when various issues pertaining to homosexuality surface. In 1988 , Congress rehed on it twice, once to restrict speech and once to attempt to alter a civil rights statute.

That spring, a local family planning clinic in New Hampshire finished work on a federally-funded sex education program for adolescents, especially males, who, researchers found, believed that impregnating their girlfriends and becoming fathers proved to peers that they were not homosexual. ${ }^{76}$ The manual written for teachers stated that "[g]ay and lesbian adolescents are perfectly nornal and their sexual attraction to members of the same sex is hcalthy."77 Senator Gordon Humphrey imtroduced legislation that passed the Senate, but died in a conference committee, which would have prohibited federal funding of sexual education materials that promoted "hoinosexu-

1. Promotes a homosexual lifestyle.

2. Portrays homosexuality as a positive alternative lifestyle.

3. Suggests that some methods of sex are safe methods of homosexual sex." Id.

73 See Ala. Code $\S 16-40 \mathrm{~A}-2$ (a)(8) (1992). Alabama requires that sex education programs include "[a]n emphasis, in a factual manner and from a public health perspective, that homosexuality is not a lifestyle acceptable to the general public and that homosexual conduct is a criminal offense under the laws of the state." Id.

74 Simon Garfield, The Age of Consent, The Independent, Nov. 10, 1991, at 3.

75 Id. The basic form of Clause 28 traveled back across the Atlantic in the form of an Oregon ballot initiative, rejected by voters in November 1992, that would have required that "[s]tate, regional and local governments and their properties and monies shall not be used to promote, encourage, or facilitate homosexuality." For the Record, Oregonian, Oct. 2, 1992, at D6.

76 Rorie Sherman, Sex Education Manual Spurs Censorship Debate, Nat'l L.J., July 18, 1988, at 14; see also Clare Kittredge, Sex-Education Dispute Settled by State, Clinic, Boston Globe, Sept. 7, 1988, at 26 (discussing how a compromise was eventually reached whereby private financing was used to finance production of the manuals and a disclaimer added disavowing any government approval of its contents).

77 Rod Paul, Sex Education Manual Prompts Moral Outrage, N.Y. Times, Apr. 24, 1988, at 39. 
ality and homosexual activity" or contained "references to homosexuality as 'normal or natural activity." "78

Also in 1988, Congress attempted to force the District of Columbia to alter its mumcipal civil rights law, one of the first to include sexual orientation as a protected category, by exempting rehigious colleges from its scope. The District's highest court had ruled that Georgetown University violated the local law by refusing to extend benefits to a lesbian and gay student group. ${ }^{79}$ Congress reacted by conditioning federal appropriations to the District on the City Council allowing religious schools to deny benefits or recognition to "any person or persons that are organized for, or engaged in, promoting, encouraging, or condoning any homosexual act, lifestyle, orientation, or behief."80 Congress never defined "homosexual belief," but its inclusion of that term signifies the recognition of and the desire to suppress something more than (and different from) either conduct ("act") or status ("orientation").

The following year, in response to public outcry over reports that National Endowment for the Arts ("NEA") funds liad supported an exhibit of homoerotic Robert Mappletliorpe photographs and otler controversial art, Congress enacted legislation prohibiting the NEA from funding obscene materials "including but not limited to, depictions of sadomasochism, homoeroticism, the sexual exploitation of children, or individuals engaged in sex acts."81 As anthropologist Carole S. Vance has pointed out, this linguistic construction collapses liowoeroticism and obscenity, nuaking the former appear to be a synonym for the latter. ${ }^{82}$ Althougl lomoerotic niaterials are simply one

78134 Cong. Rec. 10,048 (1988).

79 Gay Rights Coalition v. Georgetown Univ., 536 A.2d 1, 26 (D.C. 1987).

80 District of Columbia Appropriations Act of 1989, Pub. L. No. 100-462, \& 145(c)(3), 102 Stat. 2269 (1988). The attempt temporarily failed when City Council members won a ruling that the provision violated their free speech rights. Clarke v. United States, 886 F.2d 404 (D.C. Cir. 1989), vacated on other grounds, 915 F.2d 699 (D.C. Cir. 1990). Congress had the last word, however; it simply amended the D.C. human rights act directly, drawing on its residual power over local District government. See District of Colunibia Appropriations Act of 1990, Pub. L. No. 101-168, § 141, 103 Stat. 1267, 1284 (1989).

81 Pub. L. No. 101-121, § 304, 103 Stat. 701, 741 (1989).

82 Carole S. Vance, Misunderstanding Obscenity, Art in America, May 1990, at 49-55. As Vance notes:

[T]he list of sexual acts simply gives examples of depictions that might fall under the legal definition of obscenity, after the three prongs of the Miller test are met. But these sexual depictions or acts are not by themselves obscene. (Or, to take another example, 
example of what might meet the legal test for obscenity, the NEA restriction comes full circle from 1950 s obscemity case law by seeming to equate the two. Its message - like that of the pre-Roth obscemity cases-is that homoeroticism is obscene.

Subsequent developments in the arts funding controversy further conflated gay identity with speech about sexuality. In 1990, as congressional consideration of agency funding approached, then Chairperson of the NEA John Frohnmayer denied grants recommended by the agency's internal peer review process to four performance artists. Three of the four were lesbian or gay. In challenging the demals, the artists did not claim that they lost funding because they were gay. Rather, they asserted a viewpoint bias claim, arguing that the NEA demed funding based on two common themes in their work, one of which was the endorsement of equal legitimacy for homosexual and heterosexual practices. ${ }^{83}$

Each of these post-Briggs "no promo homo" campaigns utilized a concept of homosexuality that incorporates viewpoint. Each centered on a fight to control some public venue-whether it be arts grants, schools, or health education materials. And each represented a step farther away from the focus on conduct and privacy that had dominated earlier case law.

\section{The Evolution of IDENTITY}

The legal doctrimes most relevant to lesbian and gay civil rights litigation have evolved in tandem, not as the distinct lines of doctrime that they sometimes appear to be, but in a dynamic tension with each other. Expression, equality, and privacy coexist as components of riglits claims that are mutually dependent. The ban on military service by lesbians, gay men, and bisexuals, for example, renders identical conduct such as kissing permissible or pumshable based on the sexual orientation of the actor. ${ }^{84}$ Moreover, the ban restricts self-iden-

more easily understood because it is not about sex, consider the phrase "obscene material imcluding but not limited to black-and-white photographs, color slides and Cibachromes.")

Id. at 51 .

83 See Finley v. National Endowment for the Arts, 795 F. Supp. 1457, 1461 \& n.5 (C.D. Cal. 1992).

84 Meinoranduin from Secretary of Defense to Joint Chiefs of Staff, Policy on Homosexual Conduct in the Armed Forces, July 19, 1993. 
tifying speech with the justification that homosexual "conduct" is antithetical to morale, good order, and discipline. ${ }^{85}$ The military ban is a particularly rich example of the inextricability of the concepts of expression, equality, and privacy.

The military ban also illustrates how the boundaries of legal doctrine shape pohtical debates and decisions. In the aftermath of Bowers v. Hardwick, ${ }^{86}$ the federal judiciary divided over what has become known as the status-conduct debate, with most courts of appeal ruling that discrimination based on sexual orientation could not be subject to heightened scrutiny under the equal protection clause because it was constitutionally permissible under Hardwick for a state to criminalize sodomy, and participation in sodomy defined the class homosexual. ${ }^{87}$ Left without a privacy-based defense agamst criminalization of that conduct, advocates and some judges argued that sexual orientation was first and foremost a status, not contingent on conduct. This riddle-is homosexuality status or conduct-was purely an artifact of the categories of legal doctrine and the outcome of a single case. Yet it was picked up, replicated and amplified in the arguments over the military ban. President Clinton framed his position as opposition to discrimination "based solely on status," and, in response, congressional opponents such as Senator Sam Nunn responded in part by arguing that there was no status without conduct. That entire framework grew out of Hardwick.

The doctrinal categories themselves muddy up the law. Is the claim one of expression or of equality when a Irish gay and lesbian group is denied participation in a St. Patrick's Day parade? Is the exclusion of the group wanting to carry a self-identifying banner based on speech or based on status? Are they being shut out because of who they are or because of what they are saying? In reality, these distinctions are artificial. In the law, they carry enormous weiglit. If the defendant is a private entity, the only recourse in law is to assert an equality claim if there is a civil rights statute that includes sexual orientation as a prohibited classification. No right to freedonı of

85 President's Remarks Announcing the New Policy on Gays and Lesbians in the Military, 29 Weekly Comp. Pres. Doc. 1372 (July 26, 1993).

86478 U.S. 186 (1986).

87 See generally Nan D. Hunter, Life After Hardwick, 27 Harv. C.R.-C.L. L. Rev. 531 (1992) (discussing in detail both the origins of the distinction between status and conduct and the gaps that have arisen in this discourse). 
speech exists against private actors. The state action doctrine thus drives litigation and debate about St. Patrick's-type events into diminishing important aspects of the situation having to do specifically with endorseinent of homosexuality. Conversely, if the defendant is a pubhic entity, the more powerful tactic is often a speech claim, as the student organization cases demonstrate. ${ }^{88}$

The law needs to recognize the irrationality of these distinctions as advocates continue to press claims that require courts to consider the meaning of homosexuality. In particular, the law needs a much more clearly articulated conceptualization of the intrinsic role of expression at the very heart of equality.

Self-identifying speech does not merely reflect or communicate one's identity; it is a major factor im constructing identity. Identity cannot exist without it. That is even inore true when the distimguishing group characteristics are not visible, as is typically true of sexual orientation. Therefore, im the field of lesbian and gay civil rights, much more so than for most other equality claims, expression is a component of the very identity itself. This is a paradox that current law cannot resolve.

State-imposed penalties on identity speech-on speech that promotes or professes homosexuality-have multiple consequences.

First, penalizing self-identifymg expression effectively nullifies any protection under equality principles. As Justice William Breunan noted with respect to a plaintiff who had been fired after informing coworkers of her bisexuality, "it is realistically impossible to separate her spoken statements from her status."89 Such penalties would make the proimise of equality a sham for lesbian and gay citizens, comparable to denying religion-based protection to Jews who wear yarmulkes or Christians who wear crosses.

Second, suppression of identity speech leads to a compelled falsehood, a violation of the principle that an imdividual has the right not to speak as well as to speak..$^{90}$ In the absence of identity speech, most persons are assuined to be heterosexual. To paraphrase the ACT-UP

${ }^{88}$ See supra note 1.

89 Rowland v. Mad River Local Sch. Dist., 470 U.S. 1009, 1016 n.11 (1985) (Brennan, J., dissenting).

90 See, e.g., Wooley v. Maynard, 430 U.S. 705, 717 (1977) (holding that a state statute, which forced individuals to display messages on their private property to which they were ideologically opposed, invaded their First Amendment rights). 
slogan, silent $=$ straight. To compel silence, then, is to force persons who are not heterosexual in effect to lie.

Lastly, like forced speech, the collective, communal impact of forced silence amounts to inore than an accumulation of violations of individual integrity. It creates a form of state orthodoxy. ${ }^{91}$ If speaking identity can communicate ideas and viewpoints that dissent froin inajoritarian norms, then the selective silencing of certain identities has the opposite, totalitarian effect of enforcing conformity. In that sense, hoinosexuality is not inerely, or either, status or conduct. It is also, independently, an idea.

In the contemporary Uinted States, campaigns to secure state suppression of sexual identity speech are a complex phenoinenon. Althougli they seek to control both individuals and ideas, the target of the exclusion has shifted from the former to the latter. At stake is the role sexuality will have in the realın of public discourse.

91 Cf. West Virginia State Bd. of Educ. v. Barnette, 319 U.S. 624, 642 (1943) ("If there is any fixed star in our constitutional constellation, it is that no official, high or petty, can prescribe what shall be orthodox in politics, nationalism, religion, or other matters of opimion."). 
